\title{
ARTICLE
}

\section{'Sensory pad'- A novel chemoreceptive device in Hilsa (Tenualosa ilisha) to support its amphihaline attribute}

\author{
Subhendu Kumar Chatterjee ${ }^{1,2}$, Chandan Malick ${ }^{1,3}$, Samir Bhattacharya ${ }^{2}$, Rakesh \\ Kundu $^{3}$, Vettath Raghavan Suresh ${ }^{4}$, Surjya Kumar Saikia1* \\ ${ }^{1}$ Aquatic Ecology and Fish Biology Laboratory, Department of Zoology, Visva-Bharati University, Santiniketan-731235, \\ India \\ ${ }^{2}$ Molecular Endocrinology Laboratory, Department of Zoology, Visva-Bharati University, Santiniketan-731235, India \\ ${ }^{3}$ Cell Signaling Laboratory, Department of Zoology, Visva-Bharati University, Santiniketan-731235, India \\ ${ }^{4}$ Riverine Ecology and Fisheries Division, Central Inland Fisheries Research Institute, Barrackpore, Kolkata-700120, \\ India
}

\begin{abstract}
Hilsa, Tenualosa ilisha is an amphihaline migratory fish that performs spawning migration to selected freshwater rivers in Indo-Pacific region. It is not clear what force triggers its migration. In this paper, we attempted to describe the features of outer integument from its head region as chemosensory site which appears to play significant role in its upstream migration. We found that this area (termed as snout) has very soft and scale less tissue oriented with pit like grooves named as 'epidermal pit'. Around these pits, odorant receptor G-protein subunits (Gaq, Gas/olf and Gao) have been substantially localized. Use of DASPEI also traced this area with neuronal existence. These features in the snout likely to contribute for chemosensory requirements of the fish during upstream migration. Considering such findings, we named this area of snout as 'sensory pad'. Its position at the forefront of olfactory organ and brain may have important role in facilitating sensory reception by the fish swimming upstream to the river.
\end{abstract}

Acta Biol Szeged 62(1):1-6 (2018)

\author{
KEY WORDS \\ chemosensory \\ epidermis \\ fish migration \\ odorant receptor

\section{ARTICLE INFORMATION} \\ Submitted \\ 30 January 2018 \\ Accepted \\ 11 April 2018 \\ *Corresponding author \\ E-mail: surjyasurjya@gmail.com
}

\section{Introduction}

The Indian shad of hilsa, Tenualosa ilisha (Order: Clupeiformes; Family: Clupeidae) is an amphihaline migratory fish with remarkable commercial importance in the Indo-Pacific region, especially in India, Bangladesh and Myanmar. This anadromous fish migrates to freshwater rivers of India and Bangladesh from sea during the southwest monsoon and consequent flooding of the rivers for spawning and breeding (Ahsan et al. 2014). The major migratory period of this fish has been classified as 'summer spawning migration' (a long upstream migratory period during July-October) every year. After their preparative

\footnotetext{
Abbreviations: DAPI: 4',6-diamidino-2-phenylindole; DASPEI: 2-(4-(dimethylamino)styryl)-N-ethylpyridinium iodide; EP: epidermal pits; FITC: fluorescein isothiocyanate; PB: phosphate buffer; PBS: phosphate buffer saline; PFA: paraformaldehyde; SEM: scanning electron microscopy; SCCs: solitary chemosensory cells; ORs: odorant receptors;
}

hauls near the coastal areas for some time (body weight 450-1200 g), shoals of sexually matured adults enter into estuarine habitat heading towards riverine freshwater for breeding. They breed in certain selected stretches of riverine freshwater identified as suitable breeding zones. This is completed within 3-4 months. The immature juveniles grow in river channels and return to the sea where they spend 1-1.5 years for feeding and growth. Most likely, the anadromous stocks that ascend from sea to the river during the breeding season also return to sea after spawning (Panhwar et al. 2011). In marine water, the juveniles grow to adults and resume upstream migration once they attain sexual maturity. This is in brief the 'migratory cycle' of hilsa.

It is known that amphihaline migratory fish like salmon tracks odour from the natal river during spawning migration. For example, adults of Arctic charr are attracted to water quality and can discriminate between odours from different charr populations (Døving et al. 1974; Selset and Døving 1980). Hasler and Wisby (1951) proposed olfactory imprinting hypothesis for such odour discrimination, where various chemosensory receptor cells of olfactory system can identify natal odours for 
migration. During spawning migration, they are guided to their natal habitat with the help of such odours. However, in hilsa being a successful migratory fish, such information on migration are not available. Although, olfactory organ is a common player for migration in fish, in hilsa, we observed a soft and scale less outer integument area just above the neurocranium, the function of which is not known. We assume that this area might have significant relevance to its migration and therefore an attempt was made to reveal chemosensory details from this area of hilsa.

\section{Materials and Methods}

\section{Study sites and sample collection}

Freshwater adult hilsa $(25-30 \mathrm{~cm}$ in total length) were collected from Hooghly, a natural freshwater habitat of hilsa, and also a distributary channel of river Ganga that flows through West Bengal, India and empties to Bay of Bengal. A total of 30-35 samples were collected and preserved immediately in ice avoiding any physical aberrations to its body. We collected tissues from the outer integument from the area above the neurocranium. This portion on the head is soft and scale less with identifiable outline (Figs. 1a, b). For our convenience, we termed it as 'snout'.

\section{Sample preparation and SEM}

The tissue sections collected from snout of at least four fishes were washed with 0.1 M PB (pH 7.4) with the help of fine brush under a binocular microscope (Fig. 1c). This was followed by removal of mucus contents through treating the sample with $0.1 \mathrm{M}$ sucrose solution for 15$20 \mathrm{~min}$. After repeated washing, the samples were kept in 2.5-3.0\% glutaraldehyde in cacodylate buffer for 24 hours at $4{ }^{\circ} \mathrm{C}$. Subsequently, samples were washed with $0.1 \mathrm{M}$ PBS to remove external fixative, and preceded to standard dehydration steps with graded acetone each with two changes for $15 \mathrm{~min}$. These were dipped in acetone (acetone was passed through $\mathrm{CuSO}_{4}$ and filtrate was taken for use) for $15 \mathrm{~min}$ and followed by critical point drying and gold plating. SEM was done in a JEOL electron microscope (NEHU, Shillong, India).

\section{Sample preparation and immunofluorescence study}

From the preserved stock of fishes, tissue samples (3 replicates) from snout were treated with physiological saline, followed by fixation in a solution of $4 \%$ PFA in 0.1 $\mathrm{M} \mathrm{PB}$ (pH 7.2) for $18-20 \mathrm{~h}$ at $4{ }^{\circ} \mathrm{C}$, rinsed with $0.1 \mathrm{M} \mathrm{PBS}$ dehydrated through a graded ethanol series and embedded in paraffin (Sigma-Aldrich, USA). Serial sections at $\sim 7 \mu \mathrm{m}$ thickness were prepared using a rotary microtome, mounted on glass slides (Riviera Matsunami, Osaka, Ja-

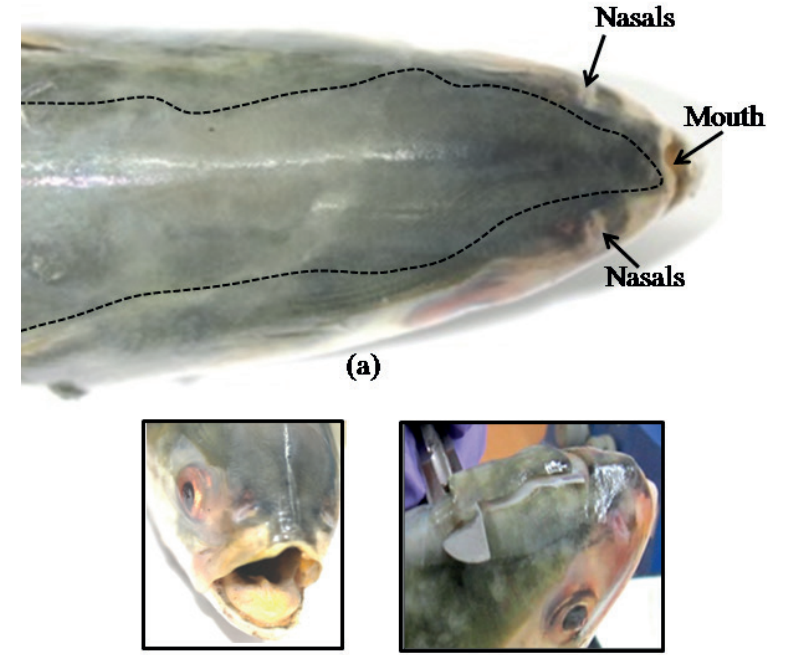

(b)

(c)

Figure 1. Sensory pad on snout region of Tenualosa ilisha. (a) The sensory pad on snout (marked with dotted line) showing positions for nasal pairs and mouth, (b) Frontal view of sensory pad and (c) Collection of tissues from sensory pad.

pan), air-dried at $4{ }^{\circ} \mathrm{C}$ and used for immunofluorescence. Deparaffinized and hydrated sections from snout were washed in chilled PBS and permeabilized with $0.5 \%$ Triton X-100 in PBS for $20 \mathrm{~min}$ at room temperature. These sections were incubated in blocking buffer $(0.5 \%$ Triton X-100 and 1\% bovine serum albumin in PBS) for one hour at room temperature and then probed overnight at $4{ }^{\circ} \mathrm{C}$ with respective mammalian polyclonal $\mathrm{G}$-protein

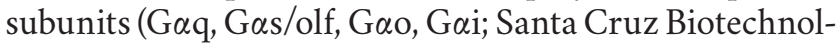
ogy) primary antibody diluted in blocking buffer (1:100). Simultaneously, a small piece of tissue (whole mount) was also processed along with the sections. After 3 washes in PBS, slides were incubated with the secondary antibody (FITC conjugated goat anti-rabbit IgG, Thermo Scientific) in diluted blocking buffer $(1: 100)$ for $1 \mathrm{~h}$ at room temperature in the dark. Slides were then washed 4 times in PBS. Vectashield mounting medium with DAPI (Vector Labs) was applied to mount glass cover slips onto the slides.

We used DASPEI that stains different type of chemosensory neurons (Leise 1996). At least three sections from the snout tissues were rinsed with $25 \mu \mathrm{g} / \mathrm{ml}$ DASPEI, washed in distilled water and kept in room temperature in the dark.

Processed sections were observed under Leica inverted microscope (DMi8) and Leica confocal microscope (DMi8).

\section{Results}

The SEM of snout showed that the snout is decorated 
with numerous openings, described as 'epidermal pits' (EPs) and arranged in a more or less regular fashion in hilsa (Fig. 2a). The average diameter of each EP is 5-10 $\mu \mathrm{m}$ with uniformly oval or round in shape and opens into the epidermal surface through a circular mouth with slightly elevated rim from the surface. The positive labelling of these pits with DASPEI also showed their neural zones around EPs under fluorescent microscope (Fig. 2b). SEM further showed numerous SCCs around the adjacent areas to the openings of EP (Fig. 2c). Histologically, EPs are spread up to the dermal tissue proper as long groove (Fig. 2d).

On treating with FITC and DAPI, the odorant receptors, $\mathrm{G} \alpha \mathrm{q}$ and $\mathrm{G} \alpha$ s/olf were found highly immunoreactive with $\mathrm{G} \alpha \mathrm{q}$ and $\mathrm{G} \alpha$ s/olf antibodies. The Figs. 3(a-c) and Figs. 3(d-f) represent $\mathrm{G} \alpha \mathrm{q}$ labelled and $\mathrm{G} \alpha \mathrm{s} /$ olf labelled areas on the snout respectively. The $\mathrm{G} \alpha \mathrm{q}$ proteins are expressed close to the surroundings of the EP, whereas, the Gas/olf proteins expressed not only around EP, but beyond the EPs on the epidermal surface. Similarly, in Figs. 4(a-c) and Figs. 4(d-f), the $\mathrm{G} \alpha \mathrm{q}$ and $\mathrm{G} \alpha \mathrm{i} 3$ labelled areas are shown. It is clear, that $\mathrm{G} \alpha$ o was expressed around the EPs, whereas, $\mathrm{G} \alpha \mathrm{i} 3$ did not show remarkable expression around EP in the snout. All the DAPI and FITC conjugated regions were merged and found to be localized to ensure their cellular

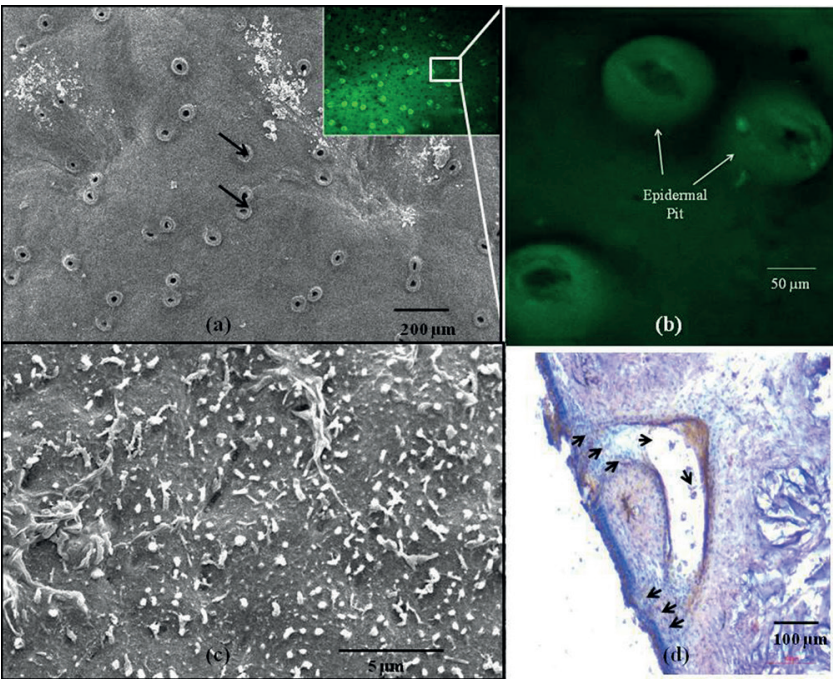

Figure 2. Structural and functional relevance of sensory pad in the snout region of Tenualosa ilisha. (a) Scanning electron microscopic view of epidermal pits. Two of such pits marked with dark arrows. DASPEI labelled epidermal pits (from Malick et al. 2018) are shown in inset. (b) Enlarged view of DASPEI labelled epidermal pits (from Malick et al. 2018). (c) Solitary chemosensory cells (SCCS) on the sensory pad of snout. (d) Groove of epidermal pit traversed to tissue proper. Black arrows show the openings of epidermal pits. (Revised figures from Malick et al. (2018) have been included to clarify the structural relevance of snout. The figures were added with due permission from authors).
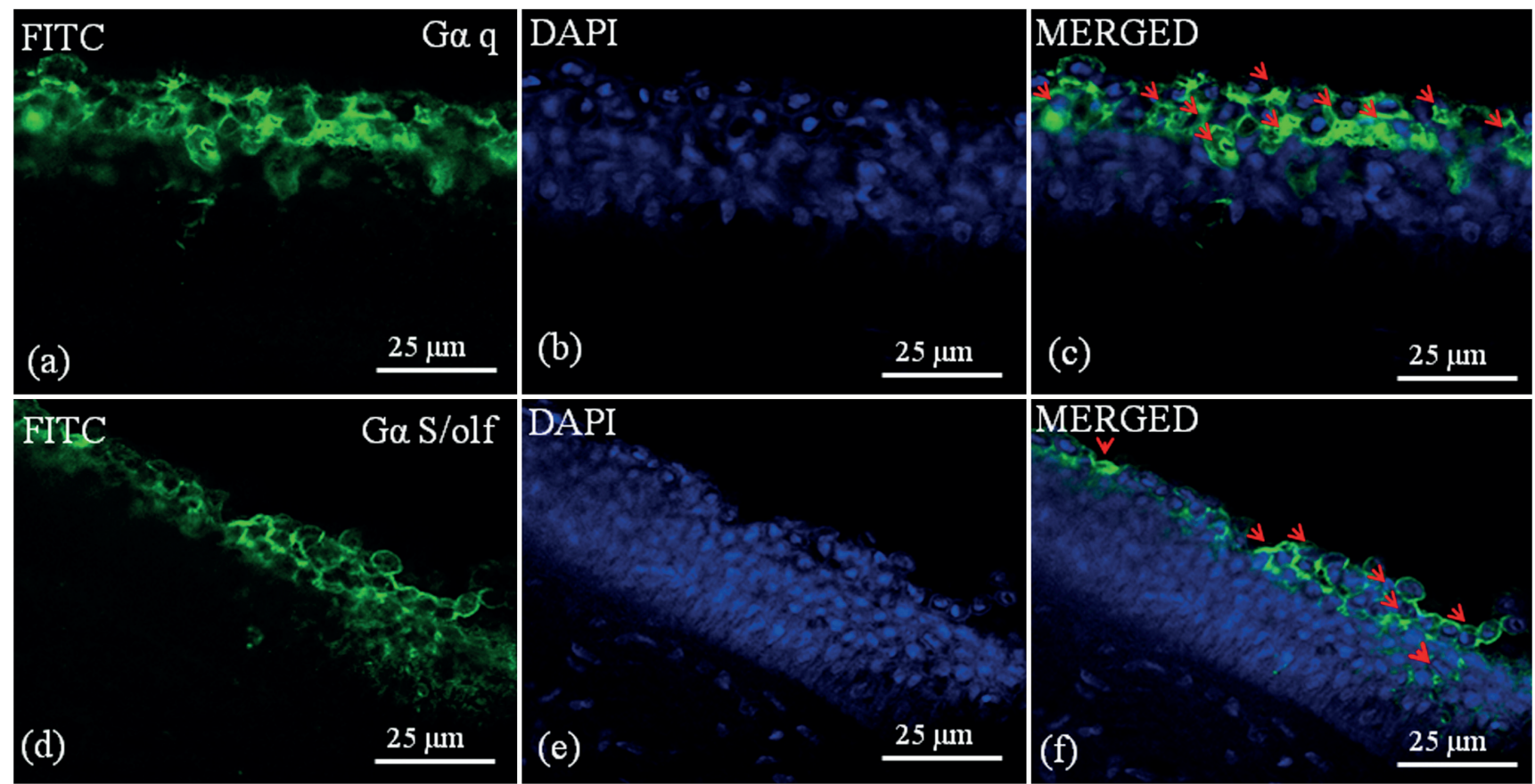

expression in the snout.
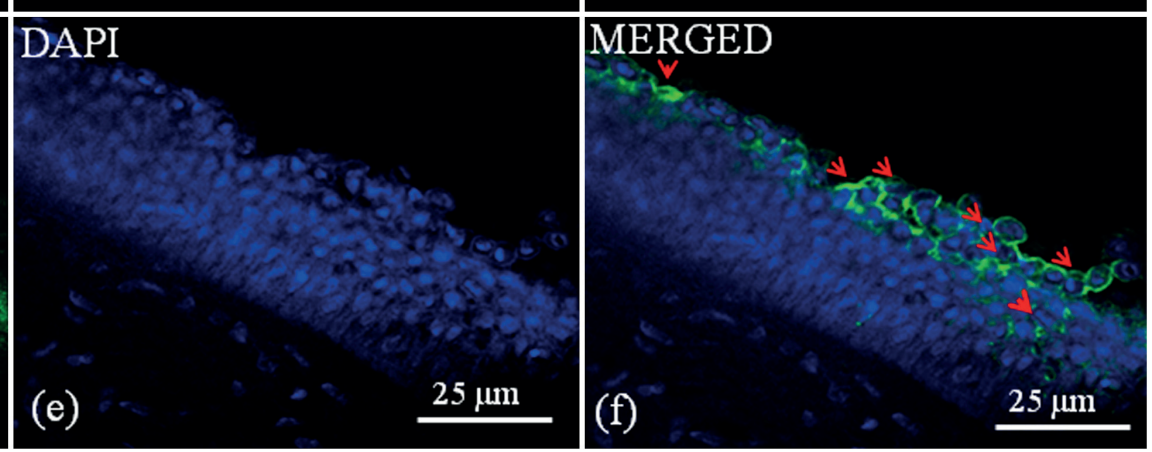

Figure 4. Expression of Gaq and Gas/olf in sensory pad of snout region of Tenualosa ilisha. (a-c) Immunofluorescence of snout against Gaq and (d-f) Gas/ olf antisera using FITC and DAPI. FITC and DAPI are merged to localize cells and antibody labelled proteins. Arrows indicate areas where Gaq and Gas/ olf are highly expressed. 

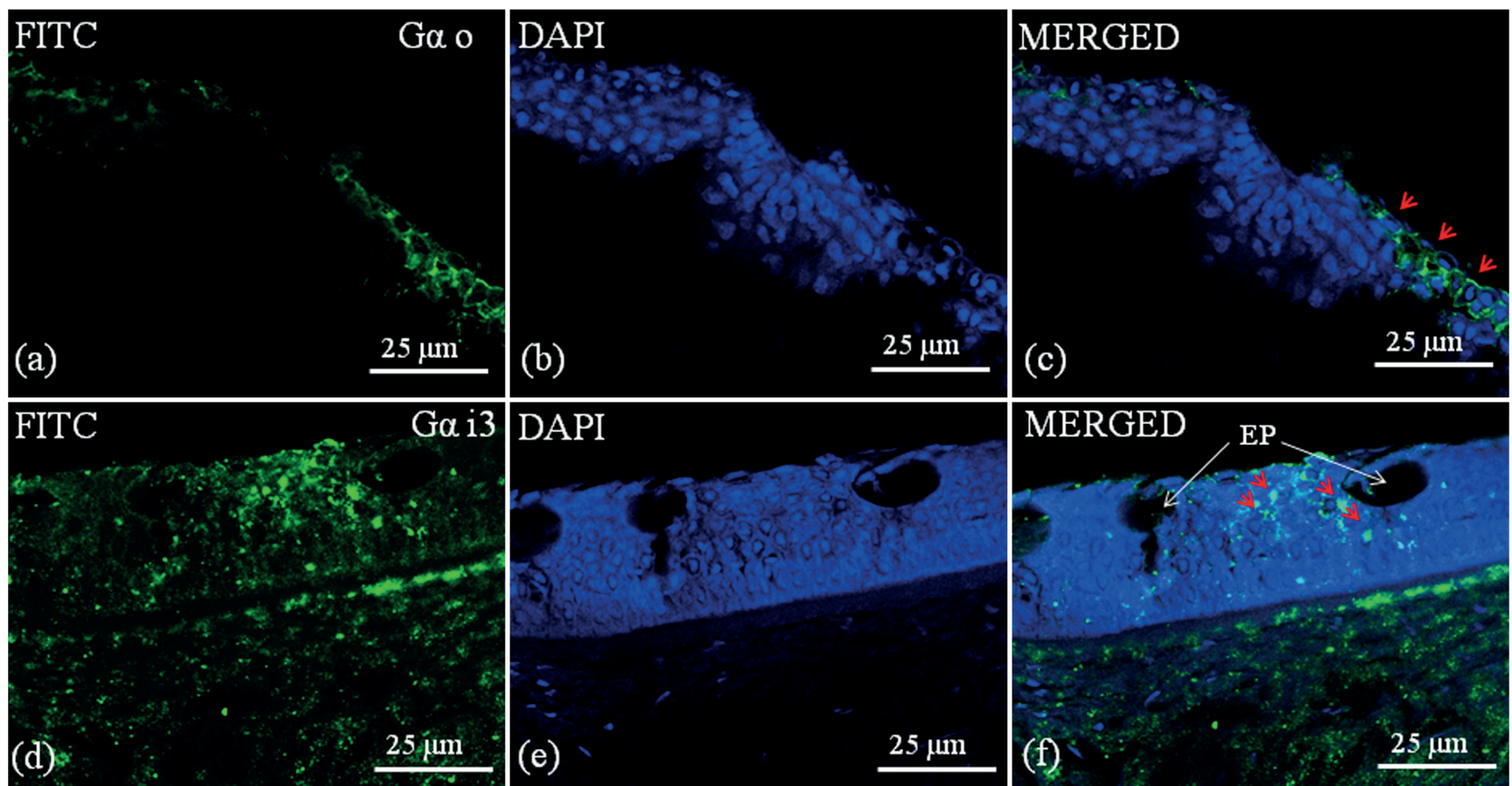

Figure 3. Expression of Gao and Gai3 on sensory pad of snout region in Tenualosa ilisha. (a-c) Immunofluorescence of snout epidermis against Gao and (d-f) Gai3 antisera using FITC and DAPI. FITC and DAPI are merged to localize cells and antibody labelled proteins. Arrows indicate areas where Gao and Gai3 are highly expressed.

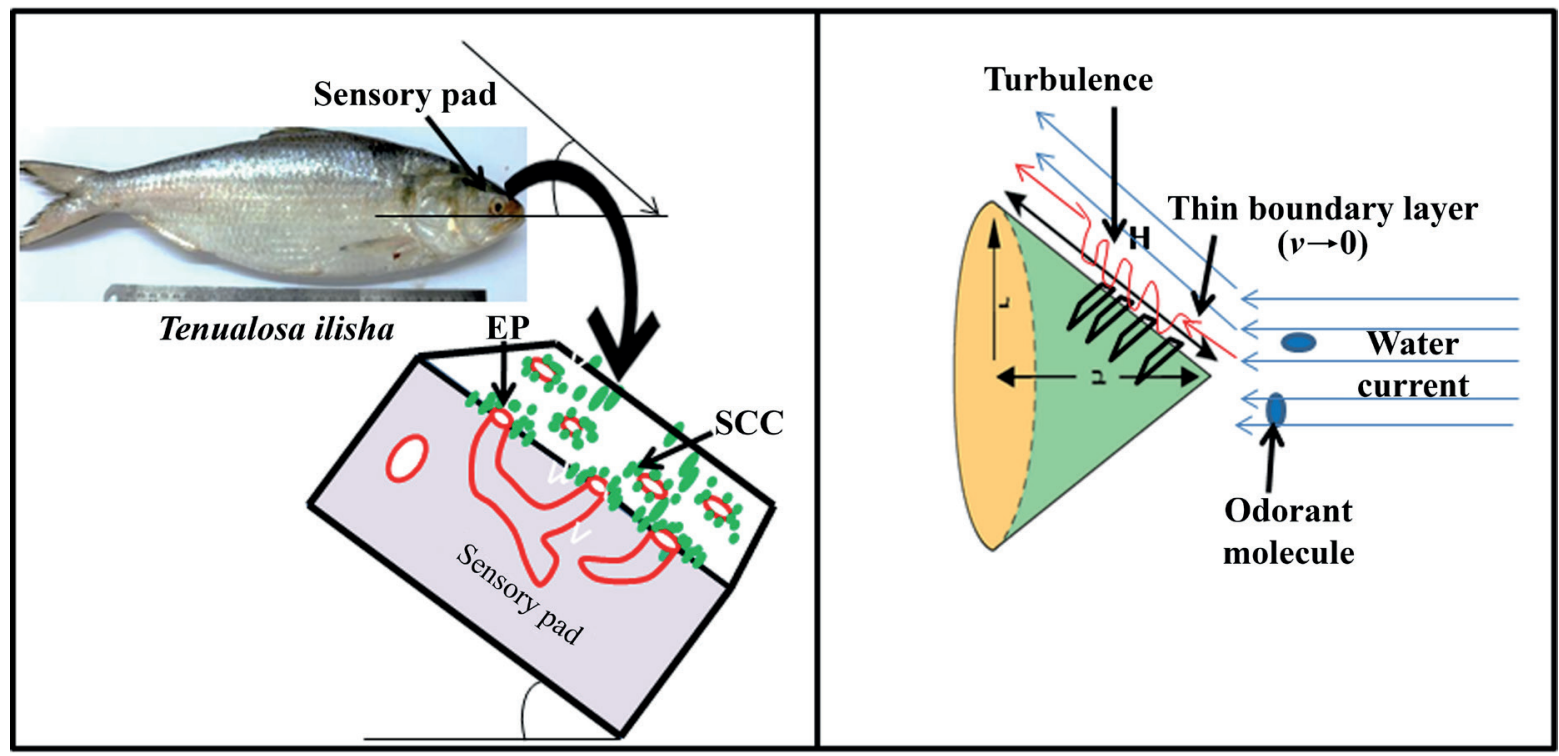

(a)

(b)

Figure 5. Hypothetical explanation on the interaction between sensory pad and natural ambience in Tenualosa ilisha. (a) Schematic diagram showing the slope of the sensory pad with sensory arrangement on the snout of hilsa (b) Possible explanation of the role of the cone shaped head with sensory arrangement in hilsa. This arrangement may create turbulence and thin boundary layer while swimming against water current to facilitate odorant reception. (EP: epidermal pit; SCC: solitary chemosensory cells). 


\section{Discussion}

In this study, the structures of the snout of hilsa from freshwater habitat were studied. It was evident that snout of adult hilsa has a soft and dark fleshy area of about 12 $\mathrm{mm}^{2}$ above the neurocranium. This area seems to face the water current when the fish swims upstream. The pit-like structure, called 'the epidermal pit' is oriented in such a way that the mouth of the pit opens to the exterior against the water current. Histological studies also confirmed that the grooves originating from epidermal pits traverse through tissue proper and open into the exterior, probably allowing water to pass through it. This is a unique arrangement not reported from any other fishes (Fig. 5a). What is more, the areas around the pit are found to be rich in SCCs. These cells are also widely scattered throughout this soft pad in the snout. From the morphological point of view, this kind of arrangement is assumed to be associated to sensory functions. Kotrschal (1992) reported that SCCs occur scattered within the epidermis of lampreys, a successful migratory fish. In amphibian, these were reported to be present in ventral skin and used to sense salt (Nagai et al. 1999). Mammals have it in their oral cavity (Sbarbati et al. 2000) as well as in respiratory epithelium of nasal passage (Saundersa et al. 2014) to sense odour. In hilsa, therefore, its presence in this area justifies the feature of chemosensory function carried out by SCCs. This is further supported by DASPEI labelling indicating existence of neuronal functions in this area.

To ascertain the chemosensory role, we have attempted to trace G-proteins subunits associated with odorant receptor or olfaction. Four of them, namely, Gas/olf, $\mathrm{G} \alpha \mathrm{q}, \mathrm{G} \alpha \mathrm{o}$ and $\mathrm{G} \alpha \mathrm{i}-3$ were tested. Of these, the G $\alpha \mathrm{s} / \mathrm{olf}$ is activated by odorant receptors at cell/outer environment interface ( $\mathrm{Li}$ et al. 2013), whereas $\mathrm{G} \alpha \mathrm{o}$ and $\mathrm{G} \alpha \mathrm{i} 3$ (and also $\mathrm{G} \alpha \mathrm{q}$ ) mediate vomeronasal olfaction on activation by ORs in vertebrates (Luo et al. 1994). Interestingly, all these G-protein subunits are found to be expressed around the epidermal pit of hilsa. Recently, Malick and co-workers (2018) also reported the expression of Gas/ olf and $\mathrm{G} \alpha \mathrm{q}$ from the epidermal cell from this area, both in adults from marine and freshwater habitats. Thus, in this fish, the expression of G-protein subunits associated with chemosensory function recognized the snout as a specially designed 'sensory pad' to facilitate upstream migration. The incoming water current probably flushes the epidermal pits and its surrounding and flows through the grooves to optimize the sensory interaction between the odorant molecules and the receptor proteins.

Hypothetically, this is acceptable that the cone shaped head of hilsa has sufficiently inclined surface with snout to enable it to create 'thin boundary layer', closure to it with turbulent water flow through grooves of EPs in the integument, thereby facilitating enough time and surface to maximize the process of odorant reception during upstream migration (Fig. 5b). Being such an efficient facilitator, it plays its role as an extraordinary 'sensory pad' for the spawning migration of the fish from sea to river.

\section{Acknowledgements}

Authors are highly thankful to National Agriculture Science Fund, Indian Council of Agriculture Research, New Delhi for their financial support to the work. The instrumental support of DST-FIST and CAS (UGC) of the Department of Zoology, Visva-Bharati to the present work is also acknowledged.

\section{References}

Ahsan DA, Naser MN, Bhaumik U, Hazra S, Bhattacharya SB (2014) Migration, Spawning Patterns and Conservation of Hilsa Shad (Tenualosa ilisha) in Bangladesh and India: Ecosystems for Life: A Bangladesh-India Initiative (in association of IUCN), Academic Foundation, Darya Ganj, New Delhi, India.

Døving KB, Nordeng H, Oakley B (1974) Single unit discrimination of fish odours released by char (Salmo alpines L.) populations. Comp Biochem Physiol A. 47:1051-1063.

Hasler AD, Wisby WJ (1951) Discrimination of stream odors by fishes and its relation to parent stream behavior. Am Nat 85(823):223-238.

Kotrschal K (1992) Quantitative scanning electron microscopy of solitary chemoreceptor cells in cyprinids and other teleosts. Env Biol Fish 35:273-282.

Leise EM (1996) Selective retention of the fluorescent dye DASPEI in a larval gastropod mollusc after paraformaldehyde fixation. Microsc Res Tech 33(6):496-500.

Li F, Ponissery-Saidu S, Yee K K, Wang H, Chen ML, Iguchi N, Zhang G, Jiang P, Reisert J, Huang L (2013) Heterotrimeric $G$ protein subunit $G \gamma 13$ is critical to olfaction. J Neurosci 33:7975-7984.

Luo Y, Lu S, Chen P, Wang D, Halpern M (1994) Identification of chemoattractant receptors and G-proteins in the vomeronasal system of Garter snakes. J Biol Chem 269:16867-16877.

Malick C, Chatterjee SK, Bhattacharya S, Suresh VR, Kundu R, Saikia SK (2018) Evidence of putative sensory receptors from snout and tongue in an upstream amphihaline migratory fish hulas Tenualosa ilisha. Ichthyol Res 65:42-55.

Nagai T, Koyama H, Hoff KS, Hillyard SD (1999) Desert toads discriminate salt taste with chemosensory function of the ventral skin. J Comp Neurol 408:125-136. 
Panhwar SK, Siddiqui G, Zarrien A (2011) Reproductive pattern and some biological features of anadromous fish Tenualosa ilisha from Pakistan. Ind J Geo-Mar Sci 40(5):687-696.

Selset R, Døving KB (1980) Behaviour of mature anadromous char (Salmo alpinus L.) towards odorants produced by smolts of their own population. Acta Physiol Scand 108(2):113-122.
Saundersa CJ, Christensenc M, Fingera TE, Tizzanoa M (2014) Cholinergic neurotransmission links solitary chemosensory cells to nasal inflammation. PNAS 111(16):6075-6080.

Sbarbati A, Crescimanno C, Bernardi V, Benati V, Merigo V, Osculati V (2000) Postnatal development of the intrinsic nervous system in the circumvallate papilla-von Ebner gland complex. Histochem J 32:483-488. 